Linköping Studies in Science and Technology.

Dissertations, No. 1757

\title{
Functional Extinctions of Species in Ecological Networks
}

\author{
Torbjörn Säterberg
}

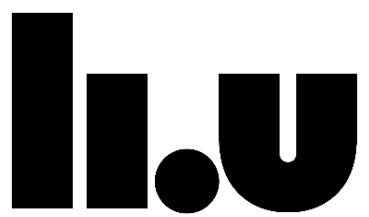

LINKÖPING UNIVERSITY

Department of Physics, Chemistry and Biology

Division of Theory and Modelling

Linköping University

SE - 58183 Linköping, Sweden

Linköping, April 2016 
Säterberg, T. 2016. Functional Extinctions of Species in Ecological Networks.

Copyright (@ Torbjörn Säterberg unless otherwise noted

Front cover: Torbjörn Säterberg

Printed in Sweden by LiU-Tryck, Linköping, Sweden, 2016

ISBN: 978-91-7685-785-4

ISSN: 0345-7524

Also available at LiU Electronic Press

http://www.ep.liu.se 
Till Olof och Hilma! 



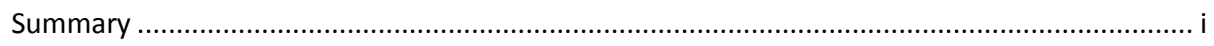

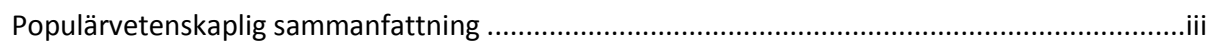

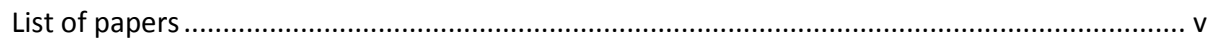

\section{PART 1 - OVERVIEW}



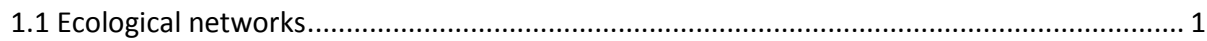

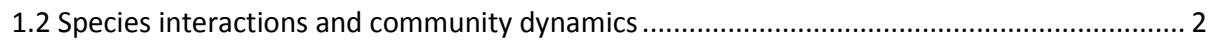

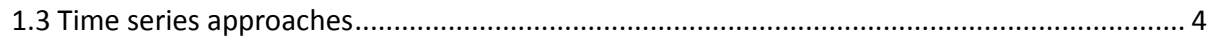

1.4 Theoretical approaches for studying press perturbations ........................................ 4

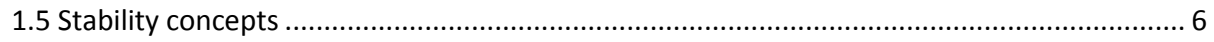

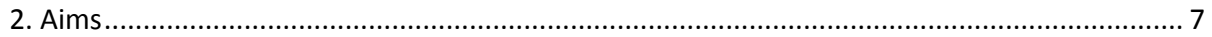

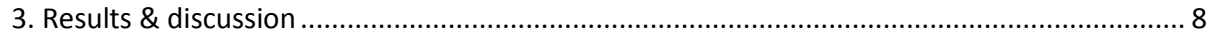

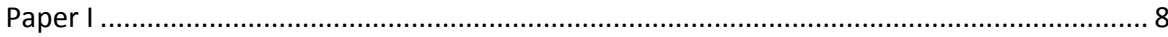

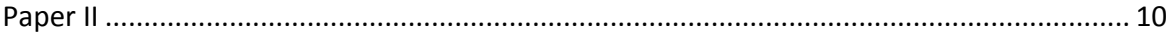

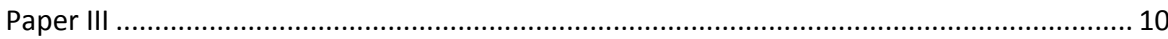

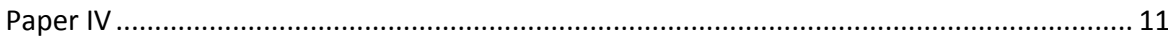

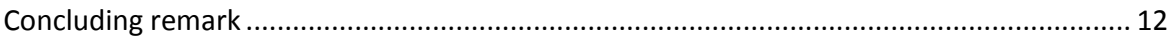



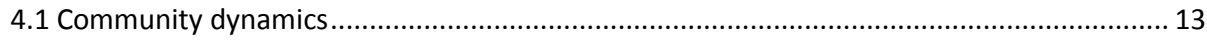

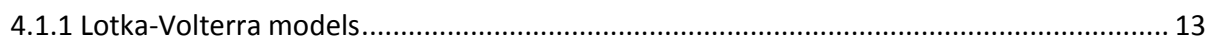

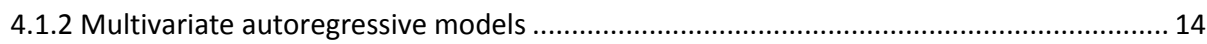

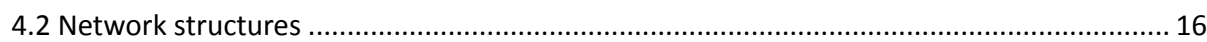

4.3 Approaches for studying perturbations to species .................................................. 17

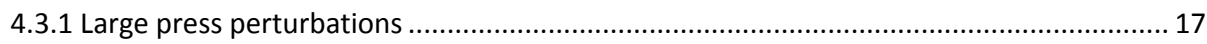

4.3.1.1 Deriving mortality rates leading to an extinction in ecological networks ....................19

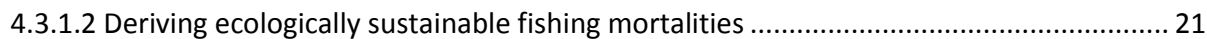

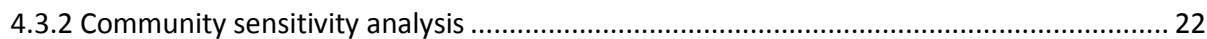

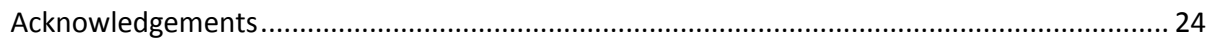

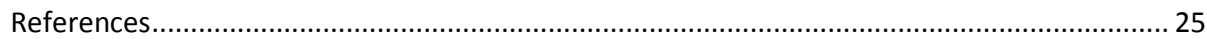

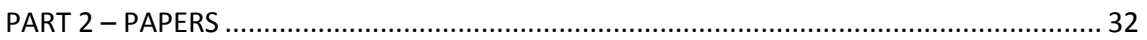




\section{Summary}

Current rates of extinctions are estimated to be around 1000 times higher than background rates that would occur without anthropogenic impacts. These extinction rates refer to the traditional view of extinctions, i.e. numerical extinctions. This thesis is about another type of extinctions: functional extinctions. Those occur when the abundance of a species is too small to uphold the species' ecologically interactive role. I have taken a theoretical approach and used dynamical models to investigate functional extinctions and threshold values for species' mortality rates in ecological networks. More specifically, I have derived threshold values for focal species mortality rates at which another species or the focal species itself goes numerically extinct (Paper I-II), or transgresses some predefined threshold abundance (Paper III). If an increased mortality rate of a focal species causes another species to go numerically extinct, the focal species can be regarded as functionally extinct, since its abundance is no longer large enough to uphold its ecologically interactive role. Such functional extinctions are investigated in the first papers (Paper I-II). In the following paper, limits for both increased and decreased mortality rates of species are explored (Paper III). Paper III also extends the basic theoretical idea developed in paper I-II into a more applied setting. In this paper I develop a time series approach aimed at estimating fishing mortalities associated with a low risk that any species in a community transgresses some predefined critical abundance threshold. In the last paper (Paper IV) the community wide effect of changes in the abundance of species is investigated.

In the first paper (Paper I) I investigate threshold levels for the mortality rate of species in ecological networks. When an increased mortality rate of a focal species causes another species to go extinct, the focal species can be characterized as functional extinct, even though it still exists. Such functional extinctions have been observed in a few systems, but their frequency and general patterns have been unexplored. Using a new analytical method the patterns and frequency of functional extinctions in theoretical and empirical ecological networks are explored. It is found that the species most likely to be the first to go extinct is not the species whose mortality rate is increased, but instead another species in the network. The species which goes extinct is often not even directly linked to the species whose mortality rate is increased, but instead indirectly linked. Further, it is found that large-bodied species at the top of food chains can only be exposed to small increases in mortality rate and small decreases in abundance before going functionally extinct compared to small-bodied species lower in the food chains. These results illustrate the potential importance of functional extinctions in ecological networks and lend support to arguments advocating a more community-oriented approach in conservation biology, with target levels for populations based on ecological functionality rather than the mere persistence of species.

In Paper II I use the approach developed in Paper I to explore the frequency and patterns of functional extinctions in ecological networks with varying proportions of mutualistic and antagonistic (predator-prey) interactions. The general results from Paper I are also found in Paper II; that is, an increased mortality rate of one focal species often first 
leads to an extinction of another species rather than to an extinction of the focal species itself.

Further, the frequency of functional extinctions is higher in networks containing a mixture of interaction types than in networks with only antagonistic interactions. Overall, this study generalize the findings of paper I for networks containing a variety of interaction types.

To make the theoretical approaches developed in paper I-II operational in a management setting I develop a time series approach aimed at estimating ecologically sustainable fishing mortalities in a multispecies fisheries context (Paper III). An ecologically sustainable fishing mortality is here defined as a long-term fishing mortality associated with a multispecies objective which infers a low risk that any species, either the focal species itself or another species, in a community transgresses a critical biomass limit, below which the risk of recruitment failure is high. The approach is exemplified using a statistical food web model of the dominating fish stocks in the Baltic Sea. For the most abundant fish stock a counterintuitive result is found; it is more likely that the multispecies objective is met if its mortality caused by fishing is increased compared to if it is decreased. Further, simultaneous changes of the fishing mortality of a number of interacting species in the food web model shows a much narrower region of possible sustainable fishing mortalities than a single species approach, something that is not captured by current stock assessment models. Altogether these results are governed by indirect effects propagating in the community and pinpoints the need to adopt community dynamical approaches in fisheries management.

The population sizes of many species in the world are declining. Negative population trends are particular pronounced in large-bodied herbivores and carnivores, species known to play important regulatory roles in many ecosystems. Although this indicates that the ecological consequence of declining populations of species might be profound, its impact on ecosystem stability remains largely unexplored. In paper IV it is therefore explored how declining populations of rare and common species affects the resilience recovery rate - of ecological networks. An analytical approximation shows that network resilience is a function of the harmonic mean of the species' abundances. This means that network resilience is especially sensitive to declining abundances of rare species. Consistent with this analytically derived result, a clear and positive relationship between resilience and the abundance of the rarest species in a broad spectrum of dynamical models of ecological networks is found. Together these results illustrate the potentially negative consequences of declining populations of rare species for the stability of the ecological systems in which they are embedded, and provide ecological arguments for the protection and management of rare species. 


\section{Populärvetenskaplig sammanfattning}

Forskning har visat att populationsstorlekarna, dvs. antalet individer som lever i ett specifikt område, minskar hos många arter. Oavsett vad som orsakar minskningen av en arts populationsstorlek, så skulle en fortsatt minskning till slut kunna leda till ett lokalt artutdöende. Den här avhandlingen handlar om en annan typ av utdöenden: funktionella utdöenden. Dessa sker när en arts populationsstorlek är för liten för att upprätthålla artens ekologiska funktion. Eftersom arter påverkar varandra på olika sätt $i$ ett ekosystem så kan en förändring i populationsstorleken hos en art få konsekvenser för andra arter. Till exempel så har överfiske av toppredatorer (t.ex. torsk) visats indirekt påverka andra organismer längre ned i näringskedjan (t.ex. växtplankton) i vissa marina system. En förändring av en arts populationsstorlek kan därmed leda till förändringar i andra arters populationsstorlekar. Men hur mycket kan en arts populationsstorlek förändras innan det får stora effekter på hela ekosystemet? Hur många bin behövs det till exempel för att pollinera ett fält? Hur stort fisketryck kan man utsätta en viss art för innan det får förödande konsekvenser för hela ekosystemet? Avhandlingen handlar om sådana tröskelnivåer, dvs. hur stor en arts populationsstorlek behöver vara och hur mycket man kan påverka en art innan den förlorar sin ekologiska funktion. Sådana tröskelnivåer undersöks här teoretiskt med hjälp av matematiska modeller. Dessa matematiska modeller beskriver hur starkt arter interagerar med varandra och hur arternas populationsstorlekar förändras över tid. Med hjälp av dessa modeller så kan man till exempel simulera hur system påverkas av olika typer av störningar; exempelvis klimatförändringar, förändringar av fisketryck och övergödning. I avhandlingens första artiklar (Artikel I-II) så antas störningen vara av generell karaktär och påverkar arter genom en förändring i deras mortalitet, vilket är ett mått på proportionen av individer $\mathrm{i}$ en population som dör per tidsenhet. För att vara mer specifik så undersöks det hur mycket en arts mortalitet kan förändras, innan den själv, eller någon annan art i det ekologiska samhället dör ut. Om en ökad mortalitet hos en art leder till ett utdöende av en annan art så kan arten som utsätts för den ökade mortaliteten ses som funktionellt utdöd. Sådana funktionella utdöenden undersöks i avhandlingens första artiklar (Artikel I-II). I artikel III så utvecklas ett statistiskt ramverk för att uppskatta ekologiskt hållbara fisketryck. Ett ekologiskt hållbart fisketryck definieras här som ett fisketryck som medför en låg risk att någon art i systemet går under en kritisk biomassa gräns - en gräns under vilken risken för reproduktionsproblem är hög. Den sista artikeln (Artikel IV) är av något annorlunda karaktär än de andra. I den undersöks det hur ekologiska nätverk, dvs. system med arter som interagerar med varandra, påverkas av förändringar i arters populationsstorlekar.

När en ökad mortalitet hos en art leder till ett utdöende av en annan art så kan arten som utsätts för den ökade mortaliteten ses som funktionellt utdöd. Sådana funktionella utdöenden har observerats i ett antal system, men den möjliga frekvensen och mönstren av sådana funktionella utdöenden har inte utforskats i detalj. Med hjälp av matematiska modeller av några empiriskt observerade och teoretiskt genererade nätverk, så undersöks mönstren och frekvensen av sådana funktionella utdöenden i avhandlingens första artikel (Artikel I). Resultaten visar att det oftast är någon annan art och inte arten själv som är den första att dö ut till följd av en ökad mortalitet. Ofta är det till och med så att arten som dör ut inte ens är direkt kopplad till arten vars mortalitet ökades. 
Överlag så illustrerar denna artikel därför den potentiella betydelsen av funktionella utdöenden och indirekta effekter i ekologiska system. Artikeln styrker därmed argument för ett holistiskt och ekologiskt orienterat förhållningssätt inom bevarandebiologin, med målnivåer för populationer baserade på ekologisk funktion i stället för ett ensidigt fokus på bevarande av arten som sådan.

I den andra artikeln (Artikel II) så används metoden som utvecklades i den första artikeln (Artikel I) för att undersöka frekvensen och mönstren av funktionella utdöenden i ekologiska nätverk med olika typer av interaktioner mellan arter. Det generella resultatet från artikel I återfinns i artikel II. En ökad mortalitet hos en art leder ofta indirekt till ett utdöende av en annan art.

För att göra den teoretiska metodiken som används i de första artiklarna (Artikel I-II) användbar i tillämpade frågeställningar så är det nödvändigt att använda så mycket information om ett system som möjligt. I artikel III så utvecklas därför en tidsseriemetod som skulle kunna användas för att uppskatta ekologiskt hållbara fisketryck i system med interagerande arter. Ett ekologiskt hållbart fisketryck definieras här som ett fisketryck som medför en låg risk att någon art i systemet går under en kritisk biomassa gräns - en gräns under vilken risken för reproduktionsproblem är hög. Metoden exemplifieras med en statistisk flerartsmodell som är baserad på tidsseriedata för de dominerande fiskarterna i Östersjön. Resultaten visar att en flerartsmodell ger andra rekommendationer för hållbara fisketryck än vad en enartsmodell ger. Överlag så pekar resultaten i denna studie därför på vikten av att införa dynamiska flerartsmodeller inom fiskerinäringen.

Populationsstorlekarna hos många av världens arter minskar. Mest uttalad är minskningen av stora rovdjur och växtätare. Det är väl känt att dessa stora djur ofta har en betydande ekologisk roll. Trots att detta tyder på att en minskning av populationsstorlekarna hos dessa typer av djur skulle kunna ha en stor effekt på ekosystemen i vilka de lever, så vet man relativt lite om effekterna av sådana populationsstorleksminskningar. I artikel IV så undersöks därför hur minskningar av ovanliga respektive vanliga arters populationsstorlekar påverkar resiliensen återhämtningstakten- i ekologiska system. En matematisk approximation visar att systemens resiliens huvudsakligen styrs av förändringar i de ovanligaste arternas populationsstorlekar. Detta resultat konfirmeras med hjälp av numeriska metoder. Överlag så tyder resultaten därmed på att ovanliga arter kan ha en betydande roll för ekosystems stabilitet och sammansättning. Studien ger därmed ett ekologiskt argument för bevarande av ovanliga arter i ekosystem. 


\section{List of papers}

I. Säterberg, T., S. Sellman \& B.Ebenman. (2013).

High frequency of functional extinctions in ecological networks. Nature, 499, 468-470. ${ }^{1}$

II. Sellman, S., T. Säterberg \& B. Ebenman. (2015).

Pattern of functional extinctions in ecological networks with a variety of interaction types.

Theoretical Ecology, 9, 83-94. ${ }^{2}$

III. Säterberg, T., M. Casini \& A. Gårdmark.

Ecologically sustainable fishing mortalities - A multispecies approach for fisheries management.

Manuscript.

IV. Säterberg, T., T. Jonsson, J. Yearsley, S. Berg \& B. Ebenman.

Declining populations of rare species decreases ecosystem resilience Manuscript.

Contributions to papers:

Paper I: TS \& BE designed the project; TS, BE \& SS performed research; TS analysed data; TS \& BE wrote the paper with contributions from SS.

Paper II: SS, TS \& BE designed the project; SS \& TS developed code; SS \& TS analysed data; BE, SS \& TS wrote the paper.

Paper III: TS designed the project with contribution from AG; TS developed code and analysed data; MC gathered data; TS wrote the paper with contributions from AG \& MC.

Paper IV: BE, TJ \& TS designed the project; SB, BE, TJ, TS and JY performed research; TS developed code and analysed data; BE wrote the paper with contributions from TJ, TS \& JY.

TS - Torbjörn Säterberg; BE - Bo Ebenman; SS - Stefan Sellman; AG - Anna Gårdmark; MC - Michele Casini; TJ - Tomas Jonsson; JY - Jon Yearsley; SB - Sofia Berg

${ }^{1}$ Reprinted with permission from Nature Publishing Group

${ }^{2}$ Reprinted with permission from Springer 
PART 1 - OVERVIEW

Functional Extinctions of Species in Ecological Networks

\author{
Torbjörn Säterberg
}






\section{Introduction}

Current rates of extinctions are estimated to be around 1000 times higher than background rates that would occur without anthropogenic impacts (Pimm et al. 2014). These extinction rates refer to the traditional view of extinctions, i.e. numerical extinctions. This thesis is about another type of extinctions: functional extinctions. Those occur when the abundance of a species is too small to uphold the species' ecologically interactive role (Soulé et al. 2003; Soulé et al. 2005; Estes et al. 2010). A school book example of a functional extinction of a species stems from the kelp-forest ecosystems around the Aleuthian Islands in northern Alaska. Because of hunting and fur trade the number of sea otters declined in this system (Estes and Palmisano 1974). In turn this led to a complete collapse of the ecosystem caused by a trophic cascade: the diminishing sea otters led to an increase in its preferred prey, sea urchins, whom in turn overgrazed the kelp-forest - leaving a barren sea floor. Notably, there appears to be a threshold abundance of sea otters above which the system tend to stay in a healthy state (Estes et al. 2010). This abundance threshold can be referred to as a species' ecologically effective population size, below which it can be considered functionally extinct. This example provides a good starting point to what this thesis is about: threshold levels for species mortality rates and densities.

Functional extinctions and ecologically effective population sizes of single species have only been observed in a few ecosystems (e.g. McConkey and Drake 2006; Estes, Tinker et al. 2010; Cury et al. 2011). But, extensive field observations (Estes et al. 2011; Möllman and Diekmann 2012; Myers et al. 2007; Baum and Worm 2009; Frank et al. 2005; Casini et al. 2008; Ripple et al. 2014) and experiments (Shurin et al. 2002; Borer et al. 2005; Sanders et al. 2013; Sanders et al. 2015) suggest the existence of trophic cascades (indirect effects caused by changed predator abundance) and regime shifts (abrupt shifts in the whole ecosystem) in a whole range of ecosystems. These empirical observation thus suggest that functional extinctions might occur in many ecosystems. To this end, I have in this thesis taken a theoretical approach and used dynamical models to theoretically explore the patterns and potential frequency of such functional extinctions in ecological networks, i.e. in systems with a large number of interacting species.

\subsection{Ecological networks}

An ecological network is a description of the interactions among species in an ecosystem, i.e. the biotic (living) part of an ecosystem (Montoya et al. 2006). The interactions among species can be represented as a binary network of who interacts with whom (Fig. 1A), but also in what way (Fig. 1C) and how strongly species interact with each other (Fig. 1B). If the strength of species interactions is considered, the dynamics of the ecological network can be described by a set of coupled equations. One such very basic description of the dynamics of interacting species is the generalized Lotka-Volterra model. In this model, the population growth rate of species is dependent on species' intrinsic growth/mortality rates and interactions among species. Three of the papers in this thesis are based on this very basic approach of modeling community dynamics. 
A)

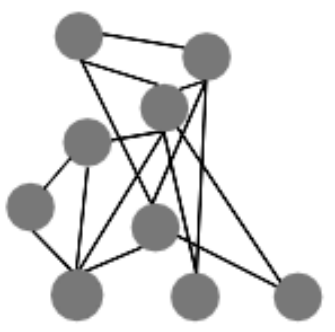

B)

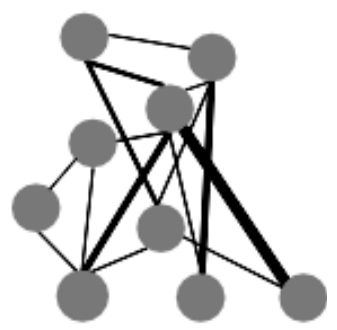

Figure 1. A graphical representation of an ecological network. A) An unweighted ecological network showing who interacts with whom. B) A weighted network describing how strongly species interact with each other (the strength of interactions is represented by the thickness of links). The links in $\boldsymbol{A}$ ) and $\boldsymbol{B}$ ) could, for example, represent antagonistic (+,-), mutualistic $(+,+)$ or direct competitive (-,-) interactions among species, as shown in $\mathbf{C}$ ).
C)

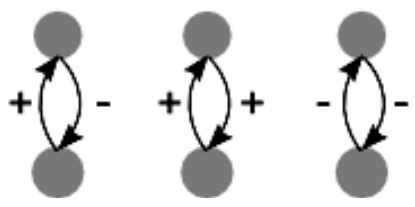

Traditionally, most research on ecological networks has focused on food webs (Vázquez et al. $2015)$, i.e. the network of species describing who feeds on whom. This might not be so surprising since all organisms are dependent on energy for survival. However, other type of ecological networks, e.g. mutualistic networks (Saavedra et al. 2011; Rohr et al. 2014; Bascompte et al. 2003; Thébault and Fontainé 2010; Olesen et al. 2007), competitive networks (Fowler 2010; Ruokolainen and Fowler 2008; Ruokolainen et al. 2007) or combinations thereof (Sauve et al. 2014; Mougi and Kondoh 2012; Mougi and Kondoh 2012; Pocock et al. 2012; Kéfi et al. 2015), have recently received an increased amount of attention. Ecological networks have been investigated in terms of press perturbations (Bender et al. 1984), i.e. sustained changes in some component of a community. How such perturbations propagate within an ecological network is dependent on the strength and the specific way that species interact.

\subsection{Species interactions and community dynamics}

At the core of ecological networks is the pairwise interactions among species. The strength with which an individual of one species affect the population growth rate of another species can be described by a function. So called functional responses (Fig. 2), have been thoroughly investigated for predator-prey interactions (Jeschke et al. 2002). Holling (1959) originally defined three basic type of equations describing the number of prey taken per individual predator, per unit of time (Fig. 2). At its most basic form a functional response can be described as a type I functional response. Here, the number of prey taken by an individual predator is a linear function of prey abundance. The type I functional response can be extended to allow for predator saturation at high prey densities - a type II functional response. The third basic type of functional response is the functional response of type III, where the number of prey taken per predator is a sigmoidal function of prey abundance (Fig. 2). Since the seminal work by Holling (1959) a number of different more mechanistically based 
functional responses have been suggested (e.g. Jeschke et al. 2002; Englund et al. 2011; Rall et al. 2012). These include, for example, temperature (Englund et al. 2011) and body size (Rall et al. 2012) dependent functional responses. Even though species interactions most likely are non-linear in nature (Jeschke et al. 2004), most papers in this thesis are based on functional responses of type I. Further, interactions for prey densities found in multispecies natural settings might, at least in some systems, be approximately linear (Novak 2010; Wootton and Emmerson 2005).

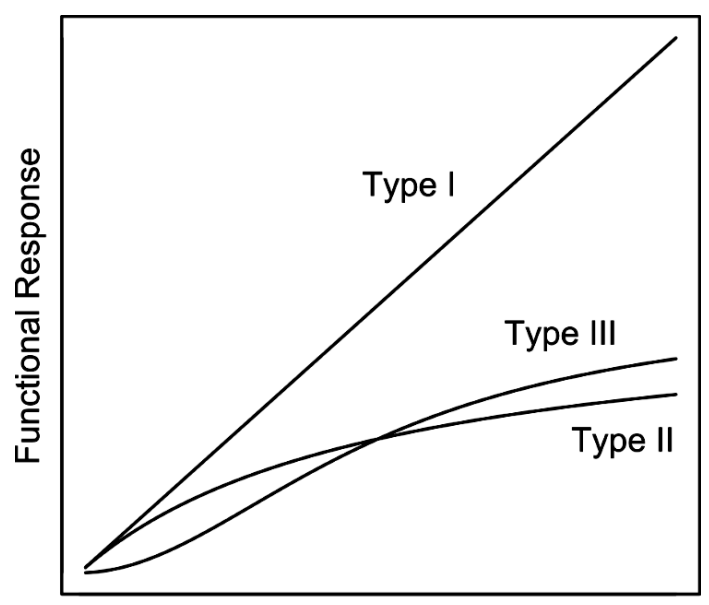

Figure 2. A schematic illustration of the three major types of functional responses: type I, type II and type III. Type I, in which the number of prey taken per individual predator per unit of time is a linear function of prey density, has mainly been used in this thesis.

Number of prey

Traditional models describing the dynamics of ecological networks have assumed parameters randomly drawn from certain intervals (e.g. May 1972; Pimm 1979; Pimm 1980; Yodzis 1988). However, since the seminal work by Yodzis \& Innes (1992), the idea of constraining parameters based on body masses of species has received increasing popularity. The model by Yodzis \& Innes (1992) has for example been used to parametrize multi trophic networks generated by the Niche-model, which is a model describing the network of who eats whom (Williams and Martinez 2000; Brose et al. 2006; Berlow et al. 2009). This model has been extensively used to derive theory based on numerical simulations (e.g. Binzer et al. 2011; Curtsdotter et al. 2011; Berlow et al. 2009; Brose et al. 2006). Recently, this framework has also been extended to mechanistically model the effect of temperature on community dynamics (Gilbert et al. 2014; Vasseur et al. 2005; O’Connor et al. 2011), using metabolic theory of ecology (Brown et al. 2004). All these studies suggest that body size scaling could be a fruitful way of parameterizing ecological models. However, all of these approaches of relating model parameters to species specific characteristics, i.e. body mass, have mainly had a focus of predator-prey interactions. Other type of interactions might be important for community stability (Kéfi et al. 2012; Mougi and Kondoh 2012; Mougi and Kondoh 2014) and thus also for the propagation of potential perturbations within a community. 


\subsection{Time series approaches}

Another potential way of parameterizing and describing the dynamics of ecological networks is to use a time series approach. Unfortunately these approaches require long time series, but they do provide a good coupling between ecological theory and empirical research (e.g. Ives et al. 2003; Francis et al. 2014). Depending on the specific research question such approaches can be used to forecast the state of specific systems, but also to derive general ecological theory (Ives et al. 2003). In recent years, non-parametric time series approaches have been developed. Their main advantage is their ability to predict the state of non-linear systems (e.g. Deyle et al. 2016; Perretti et al. 2013; Sugihara et al. 2012; Ye et al. 2015), but whether or not such models provide better forecast than simple linear autoregressive models is an open question (Ward et al. 2014). Linear models, like multivariate autoregressive models (Ives et al. 2003; Hampton et al. 2013), can easily be fitted to time series data, and have successfully predicted fish dynamics in some marine ecosystems (Lindegren et al. 2009; Lindegren et al. 2014; Bell et al. 2014). Importantly, this method can also include the effect of extrinsic environmental variables, which for sure is very important in almost any ecological system. Further, these models can be used to simulate the response of communities to press perturbations (Ives 1995) and have also given reasonable predictions to long-term sustained changes in environmental variables (Ives et al. 1999; Beisner et al. 2003).

\subsection{Theoretical approaches for studying press perturbations}

Paine (1966) showed in an intertidal community that the removal of a single predator can lead to an extinction cascade. Since then theoretical (Pimm 1979; Pimm 1980; Berlow et al. 2009; Ebenman and Jonsson 2005) as well as empirical research (Wootton 2004; Schmitz et al. 2000; Borer et al. 2005; Shurin et al. 2002) has investigated the potential effects of removing species from ecological communities. In a theoretical setting, species removal experiments have both been conducted using a topological approach (Fig. 1A) (e.g. Dunne et al. 2002), or by using dynamical models (e.g. Curtsdotter et al. 2011; Ebenman et al. 2004; Berlow et al. 2009). In a food web context, the topological approach only captures bottom up effects (species losing all their prey will go extinct), whereas the dynamical approach can reveal both bottom-up and top-down effects (Eklöf and Ebenman 2006; Curtsdotter et al. 2011). When it comes to less severe perturbations some research has focused on community sensitivity analysis (Berg et al. 2011). This framework focuses on how the equilibrium or resilience - the rate of return to equilibrium following temporary disturbances - of a community is affected by small changes in model parameters (see Tab. 1). One community sensitivity analysis is based on the negative inverse of the Jacobian matrix, whose elements gives the total direct and indirect response of species' equilibrium abundances to small additive sustained changes in the equilibrium abundance of other species. This approach has given quite puzzling results since even the sign of the responses might be hard to predict if the pairwise interactions among species are measured with error (Yodzis 1988), and the sign of the response to such perturbations might be even harder to predict for large systems (Novak et al. 2011). Furthermore, other research has also shown that indirect effects propagating in a community might very likely reverse the direct effect that one species has on another species (Montoya et 
al. 2009). These studies thus point at the importance of good estimates of pairwise interactions, but also at the counterintuitive and potentially strong indirect effects which might propagate within ecological communities.

Table 1. Some types of press perturbations exposed to single species in dynamical models of ecological communities.

\begin{tabular}{lllc}
\hline Perturbation & Response & References & Used in Paper \\
\hline Enforced extinction & $\begin{array}{l}\text { Number of secondary } \\
\text { extinctions }\end{array}$ & $\begin{array}{l}\text { (Pimm 1979; Fowler } \\
\text { 2010; Ebenman and } \\
\text { Jonsson 2005) }\end{array}$ \\
& $\begin{array}{l}\text { Changes in the } \\
\text { biomass of species }\end{array}$ & & - \\
& &
\end{tabular}

$\begin{array}{lllr}\begin{array}{l}\text { Sustained changes in } \\ \text { mortality }\end{array} & \begin{array}{l}\text { Extinction of a species } \\ \text { in an ecological } \\ \text { network }\end{array} & \begin{array}{l}\text { (Säterberg et al. 2013; } \\ \text { Sellman et al. 2015) }\end{array} & \text { I-II } \\ & \begin{array}{l}\text { Changes in the } \\ \text { biomass of species }\end{array} & \begin{array}{l}\text { (Smith et al. 2011; Ives } \\ \text { 1995) }\end{array} & \text { III }\end{array}$

\section{Small sustained}

changes in:

species' intrinsic rates

of increase

Changes in resilience

(Berg et al. 2011)

or equilibrium

abundances of species

species' equilibrium

Changes in

(Yodzis 1988; Novak et

abundances

equilibrium

al. 2011)

abundances of species

Changes in resilience

IV

per capita interaction

Changes in resilience

(Berg et al. 2011)

strengths

or equilibrium

abundances of species 


\subsection{Stability concepts}

Related to perturbations of ecological networks is the concept of stability. The robustness of a community to primary enforced extinctions, so called species deletion stability (Pimm 1980; Ebenman and Jonsson 2005), is one measure of ecological stability. But, stability is a multifaceted concept within ecology (Ives and Carpenter 2007; McCann 2000) and can for example be measured in terms of variability in population sizes (e.g. Gudmundson et al. 2015; Karlsson et al. 2007), but also in terms of the qualitative dynamical behavior of a dynamical system. One of the more traditional concepts of stability within theoretical ecology is local stability (e.g. May 1972). This is a qualitative definition of stability and infers that the system will return to equilibrium following a small temporary disturbance. The rate at which the system returns to equilibrium following a temporary disturbance - its' resilience - is determined by the dominant eigenvalue of the Jacobian matrix evaluated at the equilibrium. Related to local stability is the basin of attraction, which is the region in the multidimensional state-space which has the equilibrium as an attractor (Takeuchi 1996; van Nes and Scheffer 2007).

In contrast to a locally stable equilibrium, a globally stable equilibrium has the whole, or at least the interior, of state space as basin of attraction (Takeuchi 1996). Permanence is one global stability concept and it infers that no matter how strongly the abundances of species in a community are perturbed - as far as they are not driven to extinction - they will end up in a compact set in the interior of state space. The boundary equilibria of the system acts as repellors and constrain the species' abundances within the positive orthant of state-space (Law and Morton 1996). However, one practical problem with permanence, just as some other global stability criteria (Logofet 2005), is that it gets computationally unfeasible for large systems. 


\section{Aims}

The general aim of this thesis is to: (i) investigate threshold levels for species mortality rates in ecological networks and; (ii) to investigate the dynamical response of ecological networks to sustained perturbations. The approach is theoretical and I use coupled dynamical models to explore threshold levels for species mortality rates (Paper I-III) and the effect of changes in equilibrium abundance of species on community dynamics (Paper IV).

Specific aims:

\section{Aims of paper I}

In this paper I develop an approach to find critical mortality rates leading to extinctions of some species in an ecological network. The main aims with this paper are to:

(i) Investigate how likely it is that an increased mortality rate of one species leads to extinction of another species in the network.

(ii) Investigate the patterns of such functional extinctions within ecological networks.

\section{Aims of paper II}

In paper I, models are mainly represented by antagonistic interactions. In paper II, the aim is therefore to further investigate how the results from paper I are affected by varying the degree of mutualistic and antagonistic interactions in an ecological network. The specific aims with paper II are to:

(i) Investigate how the frequency of functional extinctions in an ecological network is affected by different proportions of mutualistic- and antagonistic interactions.

(ii) Investigate how the degree of intra-specific competition among species affects the frequency of functional extinctions.

\section{Aims of paper III}

In order to make the analytical and deterministic approach used in paper I-II applicable in real systems I develop a stochastic framework for investigating critical mortality levels. The approach is based on time series data and has a potential applied usage in fisheries management. Two specific aims with this paper are to:

(i) Develop a stochastic model for estimating ecologically sustainable fishing mortalities.

(ii) Investigate how fishing mortality limits are affected by taking a holistic multispecies approach compared to a single species approach.

\section{Aims of paper IV}

The last paper stands out from the other papers since it does not investigate the effects of changed mortality rates of species, but rather how ecological networks are affected by changes in the abundance of species. More specifically, the aim with this study is to:

(i) Investigate how resilience of ecological networks is affected by small additive changes in the abundance of focal species, and how this is related to focal species' initial abundances. 


\section{Results \& discussion}

All results in this thesis illustrate the potential importance of adopting community-oriented approaches for conservation biology and management of natural resources. This result is clearly demonstrated both from a theoretical standpoint (Paper I, II \& IV), and also in a somewhat more applied setting (Paper III).

\section{Paper I}

In 2003 Solé and co-workers (Soulé et al. 2003) gave a strong case for the existence of ecological effective population sizes of species in ecological communities. By their definition an ecologically effective population size of a species is a population size that maintain critical interactions and help ensure against ecosystem degradation. Below this population size threshold a species can be considered ecologically or functionally extinct (Jackson et al. 2001; Estes et al. 2010). The abundance of a species should thus be large enough to uphold the species ecologically interactive role. In the same vein, a theoretical framework for investigating functional extinctions and ecologically effective population sizes in ecological networks is derived in paper I. Specifically, an analytical method is developed to find how much the mortality rate of single focal species can be increased before any species in an ecological network goes extinct. If an increased mortality rate of a focal species first leads to extinction of another species rather than to extinction of the focal species itself, the focal species can be regarded as functionally extinct, even though it still exists. Using a number of different natural and computer generated networks I find that there is a high risk of functional extinctions within those systems (Fig. 3). Further, the species going extinct due to a changed mortality of a focal species is often not even directly linked to the focal species whose mortality rate is changed, i.e. it is neither a predator nor prey to the focal species (Fig. 3). These result suggest that single species approaches to conservation might not be sufficient if the ecological role of a species is considered, since other species might go extinct due to changed mortality and abundance of certain focal species (Sanders et al. 2013; Koh et al. 2004). It further suggests critical mortality rates for some species, above which interdependent species might be lost. These morality rate thresholds are shown to be related to species' average body masses. Species with large average body mass - those that in general occupy high trophic levels - can be exposed to smaller absolute changes in the mortality rate compared to species with a smaller body mass, before an extinction occurs in the ecological network. Further, a small change in the mortality rate of a species is also related to a small changes in its equilibrium abundance. This suggests that ecological networks could be more sensitive to changes in the mortality rate and abundances of top predators than to changes in the mortality rate and abundances of species at the base of food webs. 

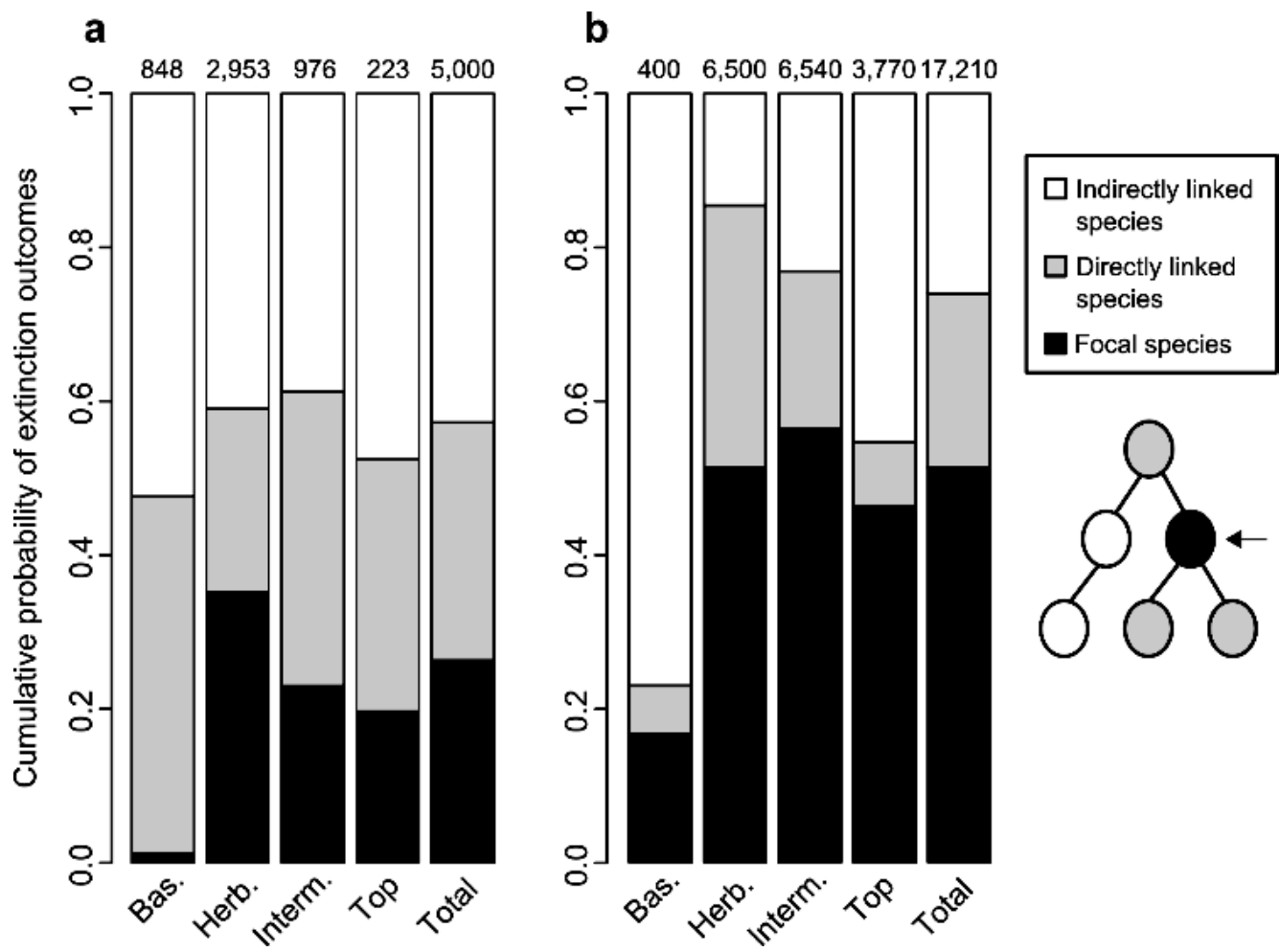

Figure 3. This figure shows that an increased mortality of one focal species (in black) often leads to an extinction of another species (grey and white) rather than to an extinction of the species itself (adapted from Säterberg et al. 2013, Nature). The figure shows the proportion of extinctions affecting the focal species itself (black), directly linked species (grey) and indirectly linked species (white) in (a) theoretically generated food webs and (b) natural food webs. The same general result, i.e. that an increased mortality rate of one species often first leads to an extinction of another species rather than to an extinction of the species itself, is found in both paper I and paper II.

In order to investigate which species that are most likely to go functionally extinct following an increase in their mortality rate, a number of species specific traits are investigated. Among those traits it is found that the total biomass of a species is an important predictor. This result is in line with another theoretical study showing that the complete removal of single species causes larger biomass changes of other species in the community, if the initially removed species has a high biomass compared to if it has a low biomass (Berlow et al. 2009).

Similarly, complex models of marine communities suggest that maximum sustainable yield fishing of forage fish species with a large biomass leads to large effects on other species in the community (Smith et al. 2011).

In paper I it is assumed that stressors only affect one species at a time. However, stressors like fishing, climate change and pollution, can be expected to strike more broadly. To this end, simultaneous stressors - in terms of fishing mortalities - are investigated in paper III. 


\section{Paper II}

Paper II is a follow up study to paper I. Here, it is investigated how robust the results from paper I are to differences in species interaction types in ecological networks. Model networks with different proportions of mutualistic interactions and antagonistic interactions (Mougi and Kondoh 2012) are built and the method developed in paper I is used to explore the frequency and patterns of functional extinctions in these systems. Overall, a high frequency of functional extinctions is found in these systems as well, corroborating the results from paper I.

In paper II it is additionally explored how the effect of different proportions of mutualistic and antagonistic interactions, and the degree of intraspecific competition among species affect the frequency of functional extinctions within these systems. It is found that the frequency of functional extinctions is higher in networks with a mixture of interaction types compared to networks with only antagonistic interactions. Furthermore, an increased degree of intraspecific competition leads to lower frequencies of functional extinctions within the networks and a decreased trophic distance (number of links) between the focal species, whose mortality rate is increased, and the species which goes numerically extinct. This result is in agreement with the general theoretical result that an increased degree of self-regulation among species tends to stabilize ecological networks (May 1972; Neutel et al. 2002; Thébault et al. 2007; Allesina and Tang 2012; Mougi and Kondoh 2012). However, it is in this study specifically found that an increased degree of self-regulation among species tend to localize the impact of press perturbations. It should further be noted that even though an increased degree of intraspecific competition tends to decrease the number of functional extinctions, there is still a large number of functional extinctions occurring, even when the average intraspecific interaction strength is about 20-30 times stronger than inter-specific interactions. This means that even if intra-specific effects where relatively strong compared to inter-specific interactions, the indirect effect caused by perturbations to single species could anyway be large in species-rich ecological systems.

\section{Paper III}

To be able to make predictions for specific ecological systems, data driven models are needed. Therefore, paper III extends the approach from paper I-II into a more applied setting. A time series approach is developed in order to estimate ecologically sustainable fishing mortalities. An ecologically sustainable fishing mortality is here defined as a long-term mean fishing mortality associated with a low risk that any species, either the focal species itself or another species, in the ecological community goes below a critical biomass limit. A statistical multispecies model based on time series of the three dominating fish species in the Baltic Sea, is used to exemplify the approach. In contrast to paper I \& II, the model used in this paper accounts for extrinsic environmental variables as well as stochastic variation in population sizes (see Fig. 5), which are all important to account for in a management setting.

By using this method of estimating ecologically sustainable fishing mortalities it is found that, in order to attain a low risk that any species transgresses its critical biomass limit, it might in some cases be more beneficial to increase the fishing mortality of certain species than what it is to decrease it. Further, simultaneous changes of the mean fishing mortality of all the three fish species in the multispecies model shows a much narrower region of simultaneous 
sustainable fishing mortalities compared a single species model. Overall, this study points to the importance of adopting multispecies models in fisheries management. Such an approach can disclose counterintuitive effects that a single species approach might not reveal.

\section{Paper IV}

In the first papers of this thesis (Paper I-III) the ecological effects of changing the mortality rate of species is explored. In contrast paper IV explores the community wide effects of changes in the abundance of species. More specifically, paper IV explores the relative importance of rare and common species in ecological networks. It is found that changes in the abundance of rare species have a large effect on network resilience - the recovery rate following temporary disturbance. This result is arrived at by an analytical approximation showing that network resilience is a function of the harmonic mean of species' abundances, meaning that changes in the abundance of a rare species has a larger effect on resilience than changes in the abundance of a common species. This analytical result is corroborated by extensive numerical investigations of a number of natural and computer generated ecological networks. Specifically, the sensitivity of resilience to additive changes in the density of species is negatively related to species abundances in those systems (Fig. 4).

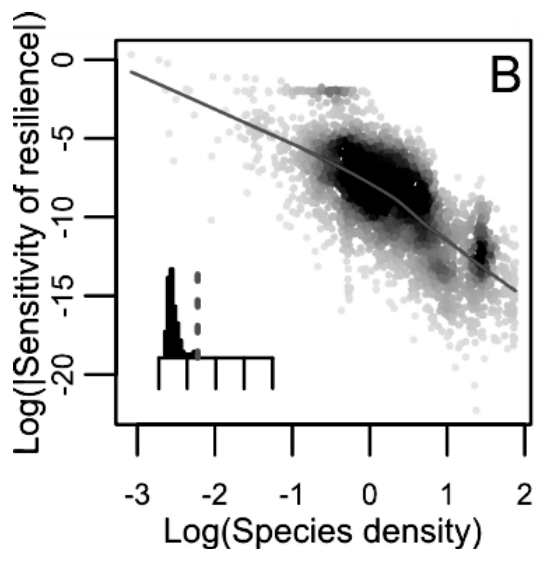

Figure 4. This figure illustrates the major result found in paper IV. The resilience - the recovery rate following temporary disturbance - of ecological networks is more sensitive to changes in the abundance of rare species than what it is to changes in the abundance of common species.

So overall, this study suggests that rare species might have an important role for the dynamics of ecological networks. A small absolute change in rare species' abundances tend to affect the dynamics more than a small change in the abundances of common species. But, which species are rare in natural systems? In terms of numerical abundance, rare species are expected to be found at the top of food webs (Brown et al. 2004). Diminished abundances of such species have been shown to lead to extinctions of other species in models of ecological communities (Paper I) and to have large community wide effects in a wide range of ecosystem (e.g. Estes et al. 2011; Baum et al. 2003; Myers et al. 2007). This suggests that such species might be of extra conservation concern. 
An important question is of course why rare species could be important for the dynamics of an ecological network. One idea is that rare species interact strongly, on per capita basis, with other species and thus that an additive change in the abundance of a rare species will lead to a larger community wide effect than an additive change in the abundance of a common species. A recent empirical work indicate that this might be the case since individuals of rare species interact more strongly, both through direct and indirect effects, with other species than more common species (Wood et al. 2010).

Overall, this study illustrates the potentially negative consequence of declining populations of rare species for the stability of the ecological systems in which they are embedded, and thus provide ecological arguments for the protection and management of rare species.

\section{Concluding remark}

Overall, this thesis points at the importance of adopting a community-oriented approach for conservation biology and management of natural resources. Using mathematical models of a variety of ecological networks it is here found that if a focal species is perturbed it is often another species that goes extinct rather than the focal species itself. This result can be set in contrast to some of the current concepts within conservation biology - like population viability analysis and minimum viable population sizes - which focuses on the conservation of single species and often neglects the dynamical effects of species interactions (Sabo 2008). Further, for fisheries management the same single species focus is often the case (e.g. Möllmann et al. 2014; Worm et al. 2009).

Most analyses in this thesis assume that perturbations affect one species at a time (Except Paper III). Simultaneous perturbations to a number of species in a community might lead to another outcome. It has for example been shown that the cascading effects of primary enforced extinctions might sometimes be counteracted by enforcing another species within a community to extinction (Sahasrabudhe and Motter 2011). Due to indirect effects caused by perturbations of a given species compensatory perturbations might therefore sometimes counterbalance the effect caused by a primary perturbation. However, this does of course depend on how and where a specific stressor affects a system. Many marine ecosystem have, for example, been selectively overfished. In many cases overfishing has started with longlived top predators and continued with overfishing of short-lived species like planktivorous fishes and invertebrates; something called fishing down the food web (Pauly et al. 1998). The historical selectivity patterns of fisheries might thus mainly have been pointed towards certain functional groups, rather than towards single species. Such a practice might be even worse for an ecological community since the functional redundancy of multiple species with similar ecological roles might be lost (see e.g. Myers et al. 2007; McClanahan et al. 2011). To this end, some advocate for balanced harvesting (Garcia et al. 2012; Zhou et al. 2010), which infers that a small proportion of the abundances of a wide range of species is removed simultaneously. This might be a fruitful way towards a sustainable management of resources because selective perturbations to species might very well lead to unwanted and strong indirect effects - even extinctions - in ecological networks. 


\section{Methods}

\subsection{Community dynamics}

Coupled dynamical models have been used to explore the community wide effects caused by changes in the mortality rate (Paper I-III) and changes in the equilibrium abundance of species (Paper IV). Continuous time Lotka-Volterra models have mainly been used in three of the papers (Paper I-II \& IV), whereas multivariate autoregressive models (MAR-models) are used to model community dynamics in paper III.

\subsubsection{Lotka-Volterra models}

Continous time Lotka-Volterra models are described by the following equation:

$$
\frac{d N_{i}}{d t}=N_{i}\left(r_{i}+\sum_{j} \alpha_{i j} N_{j}\right)
$$

Where $N_{i}$ represent the density of species $i$ in a community with $n$ species, $r_{i}$ is the intrinsic growth or mortality rate of species $i$, and $\alpha_{i j}$ is the per capita or per unit biomass effect of species $j$ on species $i$.

In matrix notation the equilibrium of a Lotka-Volterra system (eq. 1) is given by:

$\widehat{\mathbf{N}}=-\mathbf{A}^{-1} \mathbf{r}$

Where $\widehat{\mathbf{N}}$ is a column vector with species' equilibrium densities, $\mathbf{A}^{-1}$, is the invers interaction matrix with elements describing the direct and indirect effects of a change in species $j: \mathrm{s}$ intrinsic growth rate on species $i$ :s equilibrium abundance; and $\mathbf{r}$ is a column vector with intrinsic growth rates of all species.

In this thesis I have used two basic approaches to parameterize these models: (i) By drawing parameters from some preset intervals (Paper I-II) or (ii) by relating some of the parameters in the model to the average body mass of species (Paper I \& IV).

Many biological characteristics of organisms have been shown to be related to organism's body masses (Peters 1984; Brown et al. 2004; Woodward et al. 2005). In general these relationships tend follow some power function:

$Y=Y_{0} M^{a}$

Where $Y$ is the biological characteristic, $Y_{0}$ is a scaling constant, $M$ is body mass of the organism or average body mass of the species and, $a$, is scaling exponent. Typically $a$ tend to be some multiple of a quarter. These allometric relationships have for example been shown to predict intrinsic growth rates of species (Blueweiss et al. 1978), species natural mortality rates 
(McCoy and Gillooly 2008) and ingestion rates (Peters 1984). These type of relationships can thus be used to relate some parameters in a Lotka-Volterra model to species average body mass (Berg et al. 2011; Säterberg et al. 2013; Lewis and Law 2007; Lewis et al. 2008). So, given a network with known feeding interactions and average body masses it is possible derive a dynamical description of a networks with parameters inferred from the average body masses of species.

\subsubsection{Multivariate autoregressive models}

Multivariate autoregressive models (MAR-models) can easily be fitted to time series of species abundances using a variety of approaches (e.g. maximum likelihood or generalized least square). MAR-models are neatly introduced by Ives et al. (2003), and have been used extensively to infer species interactions from time series of different organisms (e.g. Ives et al. 2003; Mutshinda et al. 2009; Hampton et al. 2013; Lindegren et al. 2009). The multivariate autoregressive modeling framework is based on discrete Gompertz models:

$N_{i, t}=N_{i, t-1} \exp \left\{a_{i}-\ln \left(N_{i, t-1}\right)+\sum_{j=1}^{S} b_{i j} \ln \left(N_{j, t-1}\right)\right\}$

Where $N_{i, t}$ is the abundance of species $i$ at time $t, a_{i}$ is the specific growth rate of species $i, b_{i j}$ are interaction strengths.

On a log scale, this model simplifies to a linear difference equation:

$x_{i, t}=a_{i}+\sum_{j=1}^{S} b_{i j} * x_{j, t-1}$

where $x_{i, t}=\ln N_{i, t}$. A stochastic version of the same model is a multivariate AR(1) process given by:

$x_{i, t}=a_{i}+\sum_{j=1}^{S} b_{i j} * x_{j, t-1}+e_{i, t}$

where $e_{i, t}$ are multivariate normally distributed process errors with mean vector $\mathbf{0}$ and a covariance matrix, $\sum \mathbf{E}$, assumed to affect the per capita growth rate of species. In matrix form eq. 6 is given by:

$\mathbf{X}_{t}=\mathbf{A}+\mathbf{B} \mathbf{X}_{t-1}+\mathbf{E}_{t}$

One important thing with this model is that it can be extended to include other environmental variables assumed to have an effect on community dynamics (Ives et al. 2003). In paper III I investigate the effect of changing the fishing mortality on community dynamics using this modelling framework. Fishing mortality and additional environmental covariates are therefore included in the modelling set up. If the time series of species abundances, i.e. $\mathbf{X}_{t}$, is mean adjusted (i.e. centered around zero) and fishing mortality and other environmental covariates are also mean adjusted, the model (eq. 7) can be described as follows:

$\mathbf{X}_{t}=\mathbf{B} \mathbf{X}_{t-1}+\mathbf{C U}_{t}+\mathbf{D F} \mathbf{F}_{t}+\mathbf{E}_{t}$

Where $\mathbf{C}$ is a $S \times m$ matrix with elements $(i, j)$ giving the per unit effect of environmental covariate $j$ on the per capita growth rate of species $i, \mathbf{U}_{t}$ is a $m \times 1$ vector with environmental 
covariates at time $t, \mathbf{D}$ is a $S x S$ diagonal matrix with the per unit effect of fishing mortality on species' growth rates and $\mathbf{F}_{t}$ is a $S \times 1$ vector with fishing mortalities at time $t$.

Conditional on $\mathbf{U}_{t}$ and $\mathbf{F}_{t}$, the endogenous part, $\mathbf{X}_{t}$, is a stationary process given that all eigenvalues of the interaction matrix B lie within the unit circle (Tsay 2014). The mean and covariance of the stationary process, with environmental covariates and fishing mortalities held at their mean values, is given by:

$\boldsymbol{\mu}_{\mathrm{x}}=(\mathbf{I}-\mathbf{B})^{-1}\left(\mathbf{C} \boldsymbol{\mu}_{\mathrm{U}}+\mathbf{D} \boldsymbol{\mu}_{\mathrm{F}}\right)$

$\operatorname{Vec}\left(\mathbf{V}_{\mathrm{X}}\right)=(\mathbf{I}-\mathbf{B} \otimes \mathbf{B})^{-1} \operatorname{Vec}\left(\sum_{\mathrm{E}}+\mathbf{C} \sum_{\mathrm{U}} \mathbf{C}^{T}\right)$

Where $\boldsymbol{\mu}_{\mathrm{X}}$ is the mean vector of the stationary distribution, $\mathbf{V}_{\mathrm{X}}$ is the covariance matrix of the stationary distribution, $\mathbf{I}$, is the identity matrix, $\otimes$ refers to the tensor product and "Vec" is the vector form of a matrix in which columns of the matrix are packed on top of each other, with the first column of the matrix on top. $\boldsymbol{\mu}_{\mathrm{U}}$ and $\boldsymbol{\mu}_{\mathrm{F}}$ refers to the mean vectors of environmental covariates and fishing mortalities, respectively. Environmental covariates affect the stationary covariance by the term $\mathbf{C} \sum{ }_{U} \mathbf{C}^{\mathrm{T}}$, in which $\sum_{\mathrm{U}}$ is the covariance of the environmental covariates. This stationary distribution is used to estimate ecologically sustainable fishing mortalities in Paper III. 


\subsection{Network structures}

Throughout this thesis I have parameterized both empirically observed (Paper I \& Paper IIIIV) and computer generated network structures (Paper I-II \& IV). The network structures used in this thesis are summarized in table 2.

Table 2. This table summarize all ecological networks used in this thesis. S stands for the number of species in the community, $C$, is the connectance of the network, i.e. the proportion of possible interactions that are realized (links $\left./ S^{2}\right)$.

\begin{tabular}{|c|c|c|c|c|c|c|}
\hline Network & Paper & $\mathbf{S}$ & $\mathbf{C}$ & $\begin{array}{c}\text { Reference } \\
\text { network } \\
\text { structure }\end{array}$ & $\begin{array}{c}\text { Reference } \\
\text { Body } \\
\text { masses }\end{array}$ & $\begin{array}{c}\text { Reference } \\
\text { Parameterisation }\end{array}$ \\
\hline $\begin{array}{l}\text { Sequentially } \\
\text { assembled } \\
\text { networks }\end{array}$ & I \& IV & 50 & $\begin{array}{c}0.12 \\
\pm 0.02\end{array}$ & $\begin{array}{l}\text { (Säterberg et al. } \\
\text { 2013) }\end{array}$ & - & $\begin{array}{l}\text { (Lewis and Law } \\
\text { 2007; Säterberg et } \\
\text { al. 2013) }\end{array}$ \\
\hline $\begin{array}{l}\text { Cascade } \\
\text { model }\end{array}$ & II & 50 & 0.3 & $\begin{array}{l}\text { (Mougi and } \\
\text { Kondoh 2012) }\end{array}$ & - & $\begin{array}{l}\text { (Mougi and } \\
\text { Kondoh 2012) }\end{array}$ \\
\hline $\begin{array}{l}\text { Bipartite } \\
\text { network }\end{array}$ & II & 50 & 0.3 & $\begin{array}{l}\text { (Mougi and } \\
\text { Kondoh 2012) }\end{array}$ & - & $\begin{array}{l}\text { (Mougi and } \\
\text { Kondoh 2012) }\end{array}$ \\
\hline $\begin{array}{l}\text { Rectangular } \\
\text { food webs }\end{array}$ & I & 9 & 0.17 & $\begin{array}{l}\text { (Säterberg et al. } \\
\text { 2013) }\end{array}$ & - & $\begin{array}{l}\text { (Säterberg et al. } \\
\text { 2013) }\end{array}$ \\
\hline Baltic Sea & I \& IV & 9 & 0.19 & (Berg et al. 2011) & $\begin{array}{l}\text { (Berg et al. } \\
2011 \text { ) }\end{array}$ & $\begin{array}{l}\text { (Säterberg et al. } \\
\text { 2013) }\end{array}$ \\
\hline $\begin{array}{l}\text { Baltic Sea } \\
\text { fish } \\
\text { community }\end{array}$ & III & 3 & 0.33 & - & - & Paper III \\
\hline Lake Vättern & I \& IV & 11 & 0.18 & (Berg et al. 2011) & $\begin{array}{l}\text { (Berg et al. } \\
2011 \text { ) }\end{array}$ & $\begin{array}{l}\text { (Säterberg et al. } \\
\text { 2013) }\end{array}$ \\
\hline $\begin{array}{l}\text { Montane } \\
\text { Forest }\end{array}$ & I \& IV & 28 & 0.06 & $\begin{array}{l}\text { (Cohen et al. } \\
1990)\end{array}$ & $\begin{array}{l}\text { (Jonsson } \\
1998)\end{array}$ & $\begin{array}{l}\text { (Säterberg et al. } \\
\text { 2013) }\end{array}$ \\
\hline $\begin{array}{l}\text { Broadstrone } \\
\text { Stream }\end{array}$ & I \& IV & 28 & 0.20 & $\begin{array}{l}\text { (Woodward et al. } \\
2005 \text { ) }\end{array}$ & $\begin{array}{l}\text { (Brose et } \\
\text { al. 2005) }\end{array}$ & $\begin{array}{l}\text { (Säterberg et al. } \\
2013 \text { ) }\end{array}$ \\
\hline $\begin{array}{l}\text { Celtic Sea } \\
\text { fish } \\
\text { community }\end{array}$ & I & 67 & 0.08 & $\begin{array}{l}\text { (Barnes et al. } \\
\text { 2008) }\end{array}$ & $\begin{array}{l}\text { (Barnes et } \\
\text { al. 2008) }\end{array}$ & $\begin{array}{l}\text { (Säterberg et al. } \\
\text { 2013) }\end{array}$ \\
\hline $\begin{array}{l}\text { Skipwith } \\
\text { Pond }\end{array}$ & I \& IV & 33 & 0.32 & (Warren 1989) & $\begin{array}{l}\text { (Brose et } \\
\text { al. 2005) }\end{array}$ & $\begin{array}{l}\text { (Säterberg et al. } \\
2013 \text { ) }\end{array}$ \\
\hline $\begin{array}{l}\text { Trelease } \\
\text { Woods }\end{array}$ & I \& IV & 24 & 0.09 & $\begin{array}{l}\text { (Cohen et al. } \\
1990)\end{array}$ & $\begin{array}{l}\text { (Jonsson } \\
1998)\end{array}$ & $\begin{array}{l}\text { (Säterberg et al. } \\
\text { 2013) }\end{array}$ \\
\hline Tropic Sea & I \& IV & 19 & 0.14 & $\begin{array}{l}\text { (Cohen et al. } \\
1990)\end{array}$ & $\begin{array}{l}\text { (Jonsson, } \\
1998)\end{array}$ & $\begin{array}{l}\text { (Säterberg et al. } \\
\text { 2013) }\end{array}$ \\
\hline
\end{tabular}




\subsection{Approaches for studying perturbations to species}

Perturbations to species are introduced in two ways in this thesis: (i) by imposing large sustained press perturbations to species or (ii) by using community sensitivity analysis, which measure community wide effects caused by small changes in some model parameter. In this thesis I have induced large press perturbations through sustained changes in the mortality rate of species (Paper I-III) and community sensitivity analysis has been adopted to explore the effect of small sustained changes in the equilibrium abundance of species (Paper IV).

\subsubsection{Large press perturbations}

Large press perturbations are conducted using both Lotka-Volterra and MAR-models. The conceptual difference between the assumed responses of these models to press perturbations can be seen in Fig. 5. In the first papers (Paper I-II), I have used Lotka-Volterra models to investigate the effects of sustained changes in the intrinsic rate of increase of species. A gradual sustained change in the intrinsic rate of increase of species in a Lotka-Volerra model leads to a linear response (eq. 12) in all species' equilibrium abundances (Fig. 5A). How each species equilibrium abundance respond to a gradual change in the intrinsic growth rate of a certain focal species is determined by the inverse interaction matrix of the model (eq. 2). Thus, by changing the intrinsic growth rate parameter species equilibrium abundances respond in a deterministic and linear way using the Lotka-Volterra model (Fig. 5A). This should be set in contrast to the stochastic MAR-model's response to a gradual change in mean fishing mortality (Paper III), as seen in Fig. 5B. If the MAR-model is stationary it fluctuates around a certain mean, and if simulated over infinite time it gives a normal distribution with an analytically expressed variance (eq. 9). This distribution is shown in Fig. 5B. If it is assumed that the stationarity is not lost due to a change in the mean of the fishery induced mortality, then the response of the model to a change in mean fishing mortality can be predicted by eq. 9. Similar to the equilibrium of Lotka-Volterra models, the response of the stationary mean to a change in mean fishing mortality of a MAR-model is predicted by its inverse interaction matrix (eq. 9). 


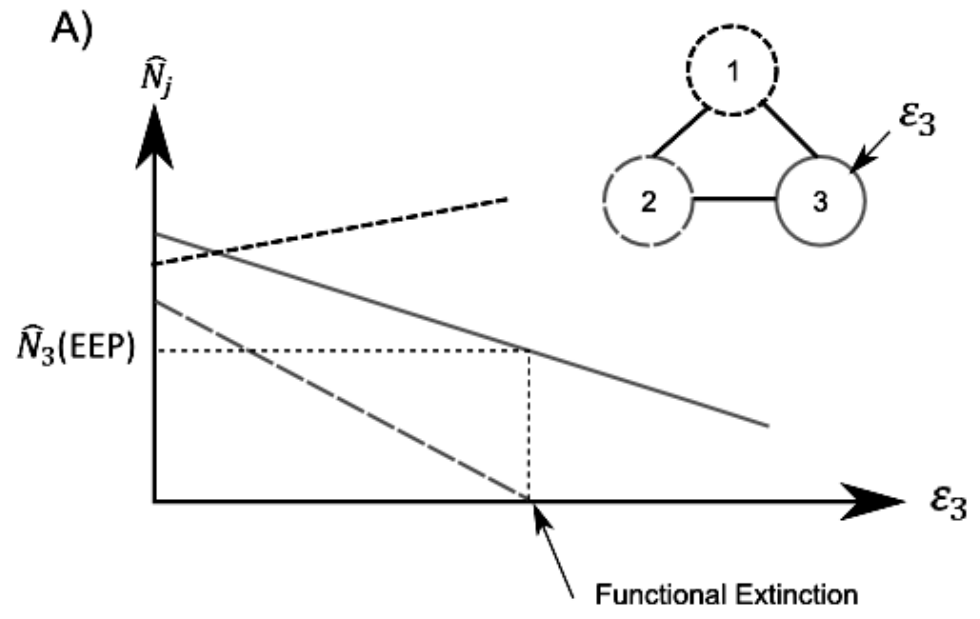

B)

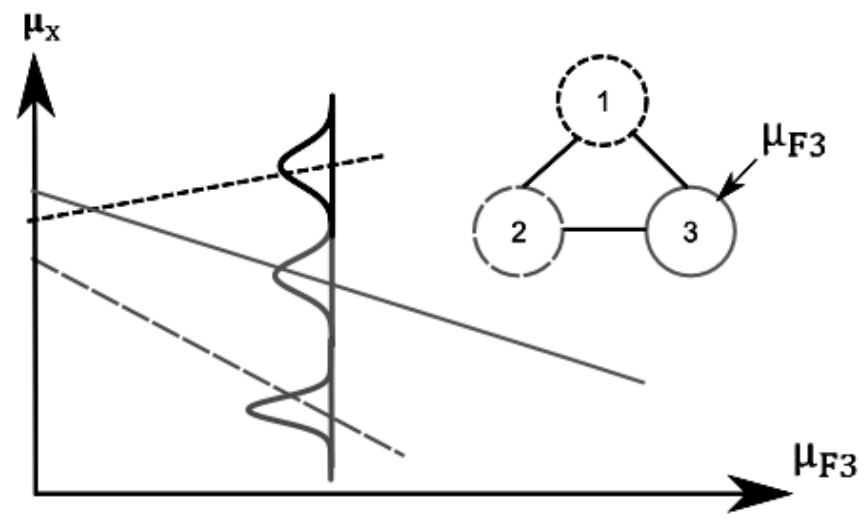

Figure 5. A schematic figure illustrating the response of the equilibrium of the Lotka-Volterra model $(\boldsymbol{A})$ and the mean of a MAR-model $(\boldsymbol{B})$, to a gradual change in one species mortality. In the Lotka-Volterra model $(\boldsymbol{A})$, an extra mortality rate, $\varepsilon_{3}$, is imposed on species no. 3. This leads to a linear change in the equilibrium abundance of all species in the system. Here, the extra mortality added to species 3 first leads to an extinction of species 2 (Paper I \& II). B) The methodological approach used in Paper III. A gradual change in the mean fishing mortality of one species, $\mu_{F 3}$, leads to a shift in the mean of the stationary distribution of a stochastic model. Instead of investigating how large mortality rate that is needed to cause an extinction (Paper I \& II), paper III instead investigates the probability that any species goes below its associated critical biomass level (not shown in this figure). This probability is found using the cumulative distribution function of the stationary distribution of the MAR-model. 


\subsubsection{Deriving mortality rates leading to an extinction in ecological networks}

Given a feasible Lotka-Volterra model (eq. 1 \& eq. 2) it is possible to derive the extra mortality rate induced to one focal species, leading to an extinction of any species in an ecological network. Starting at a feasible and locally stable equilibrium (eq. 2), the per capita intrinsic growth rate of species $j$ can be changed to a new value:

$r_{j}^{\prime}=r_{j}-\varepsilon_{j}$

Where, $\varepsilon_{j}$, is an extra mortality rate added to species $j$. In matrix notation this gives a new interior equilibrium:

$\widehat{\mathbf{N}}^{\prime}=-\mathbf{A}^{-1}\left(\mathbf{r}-\varepsilon_{j} \mathbf{e}_{j}\right)$

Where $\mathbf{e}_{j}$ is a vector with a 1 in the $j$ :th row and zero elsewhere.

The new equilibrium of species $i$ is then given by:

$\widehat{N}_{i}^{\prime}=\widehat{N}_{i}+\varepsilon_{j} \gamma_{i j}$

Where $\gamma_{i j}$ is the $(i, j)$ :th element of $\mathbf{A}^{-1}$. Setting $\widehat{N}_{i}^{\prime}=0$ in eq. 12 gives $\varepsilon_{j}(i)=-\widehat{N}_{i} / \gamma_{i j}$. This is the added mortality rate to species $j$ that will lead to an extinction of species $i$. It is possible to find, for every species $j$, the smallest added mortality, $\varepsilon_{j}$, that will lead to an extinction within the ecological network. For every species $j$ this is given by:

$\varepsilon_{j}=\min _{i}\left(\varepsilon_{j}(i): \varepsilon_{j}(i)>0\right)$

This is the minimum added mortality rate to species $j$ that will lead to an extinction within the ecological community. If the species going extinct is another species rather than the species whose mortality rate is increased (species $j$ ), species $j$ can be regarded as functionally extinct.

Thus, starting at a feasible and locally stable equilibrium point an extra mortality rate that is large enough to cause an extinction within the ecological community is added to a certain focal species. The new equilibrium (eq. 11) might be unstable. This could lead to other extinctions within the community, or to another qualitative dynamical behavior of the system. Furthermore, the system might become unstable before the extinction occurs, i.e. if the added mortality is smaller than the added morality needed to causes an extinction within the community. A local stability analysis (Tab. 3) indicate that the equilibrium of many of the ecological networks used in this thesis are stable just before the extinction occurs, and when the extinction occurs many equilibria of these systems lose their stability. 
Table 3. The proportion of ecological networks exposed to an added mortality rate that are locally stable just before an extinction occurs and after the extinction. The subdivision of the second table is based on the different parameter combinations and network types used in paper II. The three first columns of this table indicate: ( $i)$ the proportion of mutualistic links in the system; (ii) the degree of self-regulation among species in the system; and (iii) the network type.

\section{Systems used in Paper I}

Baltic Sea

Stable before

Broadstone Stream

Lake Vättern

Mountane Forest

Skipwith Pond

Tropic Sea

Trelease Woods

Celtic Sea

Sequentially assembled webs
0.56

1.0

0.90

1

1

0.81

1

0.91

0.91

\section{Stable after}

0.23

0.48

0.43

0.50

0.48

0.37

0.5

0.51

0.46

\begin{tabular}{llllr}
\hline Systems used in Paper II & & & \\
\hline Prop. mutalistic links & Degree of self-regulation & Netw_type & Stable before & Stable after \\
Antagonistic & Low & Cascade & 0.95 & 0.44 \\
Antagonistic & Low & Bipartite & 0.99 & 0.51 \\
Antagonistic & Intermediate & Cascade & 0.98 & 0.47 \\
Antagonistic & Intermediate & Bipartite & 1.0 & 0.48 \\
Antagonistic & High & Cascade & 1.0 & 0.50 \\
Antagonistic & High & Bipartite & 1.0 & 0.49 \\
Low & Low & Cascade & 0.75 & 0.32 \\
Low & Low & Bipartite & 0.59 & 0.28 \\
Low & Intermediate & Cascade & 0.81 & 0.41 \\
Low & Intermediate & Bipartite & 0.77 & 0.37 \\
Low & High & Cascade & 0.98 & 0.51 \\
Low & High & Bipartite & 0.94 & 0.48 \\
High & Low & Cascade & 0.83 & 0.37 \\
High & Low & Bipartite & 0.72 & 0.36 \\
High & Intermediate & Cascade & 0.97 & 0.47 \\
High & Intermediate & Bipartite & 0.89 & 0.45 \\
High & High & Cascade & 1.0 & 0.49 \\
High & High & Bipartite & 0.97 & 0.47 \\
& & & &
\end{tabular}




\subsubsection{Deriving ecologically sustainable fishing mortalities}

Ecologically sustainable fishing mortalities are estimated using the stationary distribution of MAR-models (eq. 9). The analytical expression for the mean of the stationary distribution of the MAR-model (eq. 9) predicts how a changed mean fishing mortality affects species abundances through indirect effects. A change in the mean fishing mortality of a species thus leads to a shift in the stationary distribution (exemplified in Fig. 5B). Each fish stock is further assumed to have an associated lower critical biomass limit, below which the risk of recruitment failure is high. By using the stationary distribution of the MAR-model (eq. 9) it is possible to derive the probability that any species in a community transgresses its critical biomass limit, given a certain mean fishing mortality. Mean fishing mortalities associated with such a probability, which is smaller than a maximum risk a manager might be willing to take, can be defined as ecologically sustainable fishing mortalities. Mathematically this can be expressed as an objective function (Fig. 6):

$\varphi\left(\boldsymbol{\mu}_{\mathrm{F}}^{\prime}\right)=\alpha-P\left(\boldsymbol{\mu}_{\mathrm{F}}^{\prime}\right)$

Where $\alpha$ is a constant giving the predefined maximum acceptable risk that a manager might be willing to take, and $P\left(\boldsymbol{\mu}_{\mathrm{F}}^{\prime}\right)$ is the probability that any species fluctuates below its Blim, given a vector of mean fishing mortalities, $\boldsymbol{\mu}_{\mathrm{F}}$.

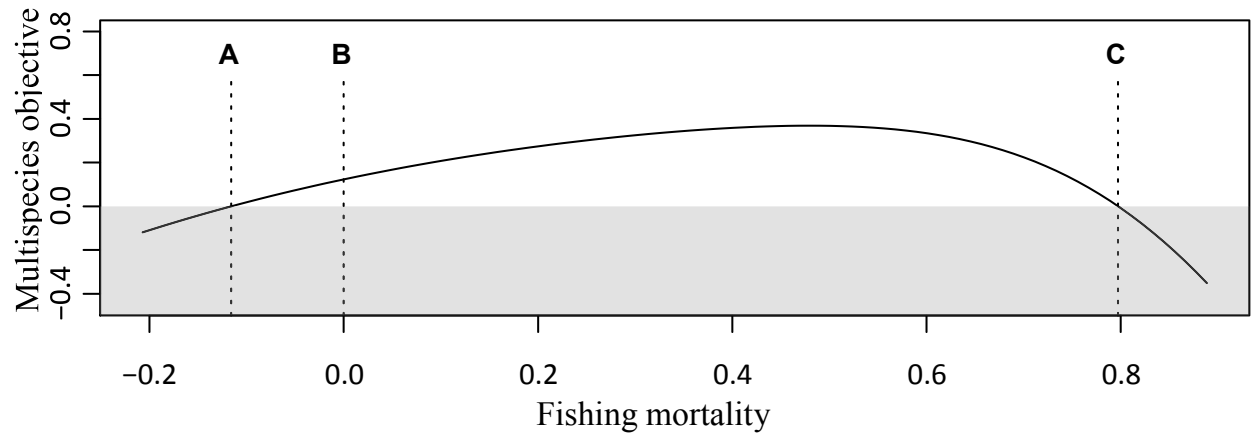

Figure 6. This figure shows the objective function used to estimate ecologically sustainable fishing mortalities in Paper III. A positive value of this multispecies objective function is associated with an ecologically sustainable fishing mortality, whereas negative values infer unsustainable fishing mortalities. The breakpoints $(\boldsymbol{A} \& \boldsymbol{C})$, where the multi species objective function is zero, reflects the limits for ecologically sustainable fishing mortalities. 


\subsubsection{Community sensitivity analysis}

Community sensitivity analysis can be used to investigate the response of the equilibrium or the resilience of a model to small sustained changes in any model parameter (Berg et al. 2011). In a Lotka-Volterra model this could be through small sustained changes in the intrinsic rates of increase, per capita interaction strengths or the equilibrium abundance of species. In this thesis, community sensitivity analysis is used to investigate the sensitivity of resilience to changes in the equilibrium abundances of species (Paper IV). This is done in order to investigate the robustness of an analytical derived approximation saying that rare species, i.e. species with a low equilibrium abundance, primarily govern resilience in systems close instability (i.e. in systems with resilience close to zero). 


\section{Acknowledgements}

First of all I would like to thank my supervisor Bo Ebenman, for giving me the opportunity to do this exciting PhD-project. I must say that I've learn a lot from you and enjoyed going to work almost every day since I started my PhD. Thanks for introducing me into the field of theoretical ecology!! Except for being an excellent supervisor, I think your most important character is being a really warm and encouraging person. It is quite easy to forget that the most important thing in life is to care about other people. This is what you do and I think it affects the atmosphere in a group quite a lot. A big contributor to the nice atmosphere in the theoretical biology group is also the other senior, Uno Wennergren, who is an unlimited source of energy and enthusiasm - it is infectious. This nice atmosphere makes it easy to do research.

I would like to thank all people who are a part, or has been, a part of the theoretical biology group during these years. It's been great to get to know all of you!! I would especially like to thank Sara Gudmundson, whom I known for more than 10 years now. It's quite funny that we started studying together at the bachelor level, continued at the master level and then did a PhD in the same group. It's been great to have such a good friend during these years. I would also especially like to thank David Gilljam, for being a really good friend. Funny that we haven't done any research together, but I hope we get the opportunity in the future. I would also like to thank my co-supervisor, Peter Münger, for taking the time when I have needed back up on mathematics and programming. Thanks to people at the Biology department; a special thanks to Karl-Olof Bergman. It's been great fun to smash the table tennis ball in the basement from time to time.

Tack till mamma och pappa för att ni har fått mig att se möjligheter istället för svårigheter!! Tack till min bror för att du är den du är!!

Till Johanna, Olof och Hilma!!

Det finns något som är viktigare än allt annat i mitt liv - min fantastiskt fina familj!! 


\section{References}

Allesina S, Tang S (2012) Stability criteria for complex ecosystems. Nature 483:205-208.

Barnes C, Bethea DM, Brodeur RD, et al (2008) Predator and Prey Body Sizes in Marine Food Webs. Ecology 89:881-881.

Barnosky AD, Matzke N, Tomiya S, et al (2011) Has the Earth's sixth mass extinction already arrived? Nature 471:51-57.

Bascompte J, Jordano P, Melián CJ, Olesen JM (2003) The nested assembly of plant-animal mutualistic networks. Proc Natl Acad Sci 100:9383-9387.

Baum JK, Myers RA, Kehler DG, et al (2003) Collapse and Conservation of Shark Populations in the Northwest Atlantic. Science 299:389-392.

Baum JK, Worm B (2009) Cascading top-down effects of changing oceanic predator abundances. J Anim Ecol 78:699-714.

Beisner BE, Ives AR, Carpenter SR (2003) The effects of an exotic fish invasion on the prey communities of two lakes. J Anim Ecol 72:331-342.

Bell RJ, Fogarty MJ, Collie JS (2014) Stability in marine fish communities. Mar Ecol Prog Ser 504:221-239.

Bender EA, Case TJ, Gilpin ME (1984) Perturbation Experiments in Community Ecology: Theory and Practice. Ecology 65:1-13.

Berg S, Christianou M, Jonsson T, Ebenman B (2011) Using sensitivity analysis to identify keystone species and keystone links in size-based food webs. Oikos 120:510-519.

Berlow EL, Dunne JA, Martinez ND, et al (2009) Simple prediction of interaction strengths in complex food webs. Proc Natl Acad Sci 106:187-191.

Binzer A, Brose U, Curtsdotter A, et al (2011) The susceptibility of species to extinctions in model communities. Basic Appl Ecol 12:590-599.

Borer ET, Seabloom EW, Shurin JB, et al (2005) What Determines the Strength of a Trophic Cascade? Ecology 86:528-537.

Brose U, Cushing L, Berlow EL, et al (2005) Body Sizes of Consumers and Their Resources. Ecology 86:2545-2545.

Brose U, Williams RJ, Martinez ND (2006) Allometric scaling enhances stability in complex food webs. Ecol Lett 9:1228-1236.

Brown JH, Gillooly JF, Allen AP, et al (2004) Toward a Metabolic Theory of Ecology. Ecology 85:1771-1789.

Casini M, Lövgren J, Hjelm J, et al (2008) Multi-level trophic cascades in a heavily exploited open marine ecosystem. Proc R Soc Lond B Biol Sci 275:1793-1801.

Cohen JE, Briand F, Newman CM (1990) Community Food Webs: Data and Theory. Springer-Verlag, Berlin.

Curtsdotter A, Binzer A, Brose U, et al (2011) Robustness to secondary extinctions: Comparing trait-based sequential deletions in static and dynamic food webs. Basic Appl Ecol 12:571-580.

Cury PM, Boyd IL, Bonhommeau S, et al (2011) Global Seabird Response to Forage Fish Depletion - One-Third for the Birds. Science 334:1703-1706.

Deyle ER, May RM, Munch SB, Sugihara G (2016) Tracking and forecasting ecosystem interactions in real time. Proc R Soc B 283:20152258. 
Dunne JA, Williams RJ, Martinez ND (2002) Network structure and biodiversity loss in food webs: robustness increases with connectance. Ecol Lett 5:558-567.

Ebenman B, Jonsson T (2005) Using community viability analysis to identify fragile systems and keystone species. Trends Ecol Evol 20:568-575.

Ebenman B, Law R, Borrvall C (2004) Community Viability Analysis: The Response of Ecological Communities to Species Loss. Ecology 85:2591-2600.

Eklöf A, Ebenman B (2006) Species loss and secondary extinctions in simple and complex model communities. J Anim Ecol 75:239-246.

Englund G, Öhlund G, Hein CL, Diehl S (2011) Temperature dependence of the functional response. Ecol Lett 14:914-921.

Estes JA, Palmisano JF (1974) Sea Otters: Their Role in Structuring Nearshore Communities. Science 185:1058-1060.

Estes JA, Terborgh J, Brashares JS, et al (2011) Trophic Downgrading of Planet Earth. Science 333:301-306.

Estes JA, Tinker MT, Bodkin JL (2010) Using Ecological Function to Develop Recovery Criteria for Depleted Species: Sea Otters and Kelp Forests in the Aleutian Archipelago. Conserv Biol 24:852-860.

Fowler MS (2010) Extinction cascades and the distribution of species interactions. Oikos 119:864-873.

Francis TB, Wolkovich EM, Scheuerell MD, et al (2014) Shifting Regimes and Changing Interactions in the Lake Washington, U.S.A., Plankton Community from 1962-1994. PLOS ONE 9:e110363. doi: 10.1371/journal.pone.0110363

Frank KT, Petrie B, Choi JS, Leggett WC (2005) Trophic Cascades in a Formerly CodDominated Ecosystem. Science 308:1621-1623.

Garcia SM, Kolding J, Rice J, et al (2012) Reconsidering the Consequences of Selective Fisheries. Science 335:1045-1047.

Gilbert B, Tunney TD, McCann KS, et al (2014) A bioenergetic framework for the temperature dependence of trophic interactions. Ecol Lett 17:902-914.

Gudmundson S, Eklöf A, Wennergren U (2015) Environmental variability uncovers disruptive effects of species' interactions on population dynamics. Proc R Soc B 282:20151126.

Hampton SE, Holmes EE, Scheef LP, et al (2013) Quantifying effects of abiotic and biotic drivers on community dynamics with multivariate autoregressive (MAR) models. Ecology 94:2663-2669.

Holling CS (1959) The components of predation as revealed by a study of small-mammal predation of the European pine sawfly. Can Entom 91:293-320

Ives AR (1995) Predicting the Response of Populations to Environmental Change. Ecology 76:926-941.

Ives AR, Carpenter SR (2007) Stability and Diversity of Ecosystems. Science 317:58-62.

Ives AR, Carpenter SR, Dennis B (1999) Community interaction webs and zooplankton responses to planktivory manipulations. Ecology 80:1405-1421.

Ives AR, Dennis B, Cottingham KL, Carpenter SR (2003) Estimating community stability and ecological interactions from time-series data. Ecol Monogr 73:301-330. 
Jackson JBC, Kirby MX, Berger WH, et al (2001) Historical Overfishing and the Recent Collapse of Coastal Ecosystems. Science 293:629-637.

Jeschke JM, Kopp M, Tollrian R (2002) Predator Functional Responses: Discriminating Between Handling and Digesting Prey. Ecol Monogr 72:95-112.

Jeschke JM, Kopp M, Tollrian R (2004) Consumer-food systems: why type I functional responses are exclusive to filter feeders. Biol Rev 79:337-349.

Jonsson T (1998) Food webs and the distribution of body sizes. PhD Thesis, Linköping Studies in Science and Technology, Dissertation No. 535. Linköping, Sweden.

Karlsson P, Jonsson T, Jonsson A (2007) Food web structure and interaction strength pave the way for vulnerability to extinction. J Theor Biol 249:77-92.

Kéfi S, Berlow EL, Wieters EA, et al (2015) Network structure beyond food webs: mapping non-trophic and trophic interactions on Chilean rocky shores. Ecology 96:291-303.

Kéfi S, Berlow EL, Wieters EA, et al (2012) More than a meal... integrating non-feeding interactions into food webs. Ecol Lett 15:291-300.

Koh LP, Dunn RR, Sodhi NS, et al (2004) Species Coextinctions and the Biodiversity Crisis. Science 305:1632-1634.

Law R, Morton RD (1996) Permanence and the Assembly of Ecological Communities. Ecology 77:762-775.

Lewis HM, Law R (2007) Effects of dynamics on ecological networks. J Theor Biol 247:6476.

Lewis HM, Law R, McKane AJ (2008) Abundance-body size relationships: the roles of metabolism and population dynamics. J Anim Ecol 77:1056-1062.

Lindegren M, Andersen KH, Casini M, Neuenfeldt S (2014) A metacommunity perspective on source-sink dynamics and management: the Baltic Sea as a case study. Ecol Appl 24:1820-1832.

Lindegren M, Möllmann C, Nielsen A, Stenseth NC (2009) Preventing the collapse of the Baltic cod stock through an ecosystem-based management approach. Proc Natl Acad Sci 106:14722-14727.

Logofet DO (2005) Stronger-than-Lyapunov notions of matrix stability, or how "flowers" help solve problems in mathematical ecology. Linear Algebra Its Appl 398:75-100.

May RM (1972) Will a Large Complex System be Stable? Nature 238:413-414.

McCann KS (2000) The diversity-stability debate. Nature 405:228-233.

McClanahan TR, Graham NAJ, MacNeil MA, et al (2011) Critical thresholds and tangible targets for ecosystem-based management of coral reef fisheries. Proc Natl Acad Sci 108:17230-17233.

McConkey KR, Drake DR (2006) Flying foxes cease to function as seed despersers long before they become rare. Ecology 87:271-276.

McCoy MW, Gillooly JF (2008) Predicting natural mortality rates of plants and animals. Ecol Lett 11:710-716.

Möllmann C, Diekmann R (2012) Chapter 4 - Marine Ecosystem Regime Shifts Induced by Climate and Overfishing: A Review for the Northern Hemisphere. Adv Ecol Res. Academic Press, pp 303-347. 
Möllmann C, Lindegren M, Blenckner T, et al (2014) Implementing ecosystem-based

fisheries management: from single-species to integrated ecosystem assessment and advice for Baltic Sea fish stocks. ICES J Mar Sci J Cons 71:1187-1197.

Montoya JM, Pimm SL, Solé RV (2006) Ecological networks and their fragility. Nature 442:259-264.

Montoya JM, Woodward G, Emmerson MC, Solé RV (2009) Press perturbations and indirect effects in real food webs. Ecology 90:2426-2433.

Mougi A, Kondoh M (2014) Stability of competition-antagonism-mutualism hybrid community and the role of community network structure. J Theor Biol 360:54-58.

Mougi A, Kondoh M (2012) Diversity of Interaction Types and Ecological Community Stability. Science 337:349-351.

Mutshinda CM, O'Hara RB, Woiwod IP (2009) What drives community dynamics? Proc R Soc B Biol Sci rspb.2009.0523.

Myers RA, Baum JK, Shepherd TD, et al (2007) Cascading Effects of the Loss of Apex Predatory Sharks from a Coastal Ocean. Science 315:1846-1850.

Nes EH van, Scheffer M (2007) Slow Recovery from Perturbations as a Generic Indicator of a Nearby Catastrophic Shift. Am Nat 169:738-747.

Neutel A-M, Heesterbeek JAP, de Ruiter PC (2002) Stability in Real Food Webs: Weak Links in Long Loops. Science 296:1120-1123.

Novak M (2010) Estimating interaction strengths in nature: experimental support for an observational approach. Ecology 91:2394-2405.

Novak M, Wootton JT, Doak DF, et al (2011) Predicting community responses to perturbations in the face of imperfect knowledge and network complexity. Ecology 92:836-846.

O'Connor MI, Gilbert B, Brown CJ, et al (2011) Theoretical Predictions for How Temperature Affects the Dynamics of Interacting Herbivores and Plants. Am Nat 178:626-638.

Olesen JM, Bascompte J, Dupont YL, Jordano P (2007) The modularity of pollination networks. Proc Natl Acad Sci 104:19891-19896.

Paine RT (1966) Food Web Complexity and Species Diversity. Am Nat 100:65-75.

Perretti CT, Sugihara G, Munch SB (2013) Nonparametric forecasting outperforms parametric methods for a simulated multispecies system. Ecology 94:794-800.

Peters RH (1984) The ecological implications of body size. Cambridge University Press, Cambridge.

Pimm SL (1979) Complexity and Stability: Another Look at MacArthur's Original Hypothesis. Oikos 33:351-357.

Pimm SL (1980) Food Web Design and the Effect of Species Deletion. Oikos 35:139-149.

Pimm SL, Jenkins CN, Abell R, et al (2014) The biodiversity of species and their rates of extinction, distribution, and protection. Science 344:1246752.

Pocock MJO, Evans DM, Memmott J (2012) The Robustness and Restoration of a Network of Ecological Networks. Science 335:973-977.

Rall BC, Brose U, Hartvig M, et al (2012) Universal temperature and body-mass scaling of feeding rates. Phil Trans R Soc B 367:2923-2934. 
Ripple WJ, Estes JA, Beschta RL, et al (2014) Status and Ecological Effects of the World's Largest Carnivores. Science 343:1241484.

Rohr RP, Saavedra S, Bascompte J (2014) On the structural stability of mutualistic systems. Science 345:1253497.

Ruokolainen L, Fowler MS (2008) Community extinction patterns in coloured environments. Proc R Soc Lond B Biol Sci 275:1775-1783.

Ruokolainen L, Fowler MS, Ranta E (2007) Extinctions in competitive communities forced by coloured environmental variation. Oikos 116:439-448.

Saavedra S, Stouffer DB, Uzzi B, Bascompte J (2011) Strong contributors to network persistence are the most vulnerable to extinction. Nature 478:233-235.

Sahasrabudhe S, Motter AE (2011) Rescuing ecosystems from extinction cascades through compensatory perturbations. Nat Commun 2:170.

Sanders D, Kehoe R, van Veen FJF (2015) Experimental Evidence for the PopulationDynamic Mechanisms Underlying Extinction Cascades of Carnivores. Curr Biol 25:3106-3109.

Sanders D, Sutter L, van Veen FJF (2013) The loss of indirect interactions leads to cascading extinctions of carnivores. Ecol Lett 16:664-669.

Säterberg T, Sellman S, Ebenman B (2013) High frequency of functional extinctions in ecological networks. Nature 499:468-470.

Sauve AMC, Fontaine C, Thébault E (2014) Structure-stability relationships in networks combining mutualistic and antagonistic interactions. Oikos 123:378-384.

Schmitz OJ, Hambäck PA, Beckerman AP, et al (2000) Trophic Cascades in Terrestrial Systems: A Review of the Effects of Carnivore Removals on Plants. Am Nat 155:141153.

Sellman S, Säterberg T, Ebenman B (2015) Pattern of functional extinctions in ecological networks with a variety of interaction types. Theor Ecol 9:83-94.

Shurin JB, Borer ET, Seabloom EW, et al (2002) A cross-ecosystem comparison of the strength of trophic cascades. Ecol Lett 5:785-791.

Smith ADM, Brown CJ, Bulman CM, et al (2011) Impacts of Fishing Low-Trophic Level Species on Marine Ecosystems. Science 333:1147-1150.

Soulé ME, Estes JA, Berger J, Del Rio CM (2003) Ecological Effectiveness: Conservation Goals for Interactive Species. Conserv Biol 17:1238-1250.

Soulé ME, Estes JA, Miller B, Honnold DL (2005) Strongly Interacting Species: Conservation Policy, Management, and Ethics. BioScience 55:168-176.

Sugihara G, May R, Ye H, et al (2012) Detecting Causality in Complex Ecosystems. Science 338:496-500.

Takeuchi Y (1996) Global dynamical properties of Lotka-Volterra systems. World Scientific Publishing, Singapore.

Thébault E, Fontaine C (2010) Stability of Ecological Communities and the Architecture of Mutualistic and Trophic Networks. Science 13:853-856.

Thébault E, Huber V, Loreau M (2007) Cascading extinctions and ecosystem functioning: contrasting effects of diversity depending on food web structure. Oikos 116:163-173.

Wootton T (2004) Markov chain models predict the consequences of experimental extinctions. Ecol Lett 7:653-660. 
Tsay RS (2014) Multivariate time series analysis : with R and financial applications. Wiley, Hoboken, New Jersey.

Vasseur DA, McCann KS, Morin AEPJ, Losos EJB (2005) A Mechanistic Approach for Modeling Temperature-Dependent Consumer-Resource Dynamics. Am Nat 166:184198.

Vázquez DP, Ramos-Jiliberto R, Urbani P, Valdovinos FS (2015) A conceptual framework for studying the strength of plant-animal mutualistic interactions. Ecol Lett 18:385400.

Ward EJ, Holmes EE, Thorson JT, Collen B (2014) Complexity is costly: a meta-analysis of parametric and non-parametric methods for short-term population forecasting. Oikos 123:652-661.

Warren PH (1989) Spatial and Temporal Variation in the Structure of a Freshwater Food Web. Oikos 55:299-311.

Williams RJ, Martinez ND (2000) Simple rules yield complex food webs. Nature 404:180 183.

Wood SA, Lilley SA, Schiel DR, Shurin JB (2010) Organismal traits are more important than environment for species interactions in the intertidal zone. Ecol Lett 13:1160-1171.

Woodward G, Speirs DC, Hildrew AG (2005) Quantification and Resolution of a Complex, Size-Structured Food Web. Adv Ecol Res. Academic Press, pp 85-135.

Wootton JT, Emmerson M (2005) Measurement of Interaction Strength in Nature. Annu Rev Ecol Evol Syst 36:419-444.

Worm B, Hilborn R, Baum JK, et al (2009) Rebuilding Global Fisheries. Science 325:578585.

Ye H, Beamish RJ, Glaser SM, et al (2015) Equation-free mechanistic ecosystem forecasting using empirical dynamic modeling. Proc Natl Acad Sci 112:E1569-E1576.

Yodzis P (1988) The Indeterminacy of Ecological Interactions as Perceived Through Perturbation Experiments. Ecology 69:508-515.

Yodzis P, Innes S (1992) Body size and consumer-resource dynamics. Am Nat 139:11511175.

Zhou S, Smith ADM, Punt AE, et al (2010) Ecosystem-based fisheries management requires a change to the selective fishing philosophy. Proc Natl Acad Sci 107:9485-9489. 



\section{PART 2 - PAPERS}

I. Säterberg, T., S. Sellman \& B.Ebenman. (2013).

High frequency of functional extinctions in ecological networks.

Nature, 499, 468-470. ${ }^{1}$

II. Sellman, S., T. Säterberg \& B. Ebenman. (2015).

Pattern of functional extinctions in ecological networks with a variety of interaction types.

Theoretical Ecology, 9, 83-94. ${ }^{2}$

III. Säterberg, T., M. Casini \& A. Gårdmark.

Ecologically sustainable fishing mortalities - A multispecies approach for fisheries management.

Manuscript.

IV. Säterberg, T., T. Jonsson, J. Yearsley, S. Berg \& B. Ebenman.

Declining populations of rare species decreases ecosystem resilience

Manuscript. 



\section{Papers}

The articles associated with this thesis have been removed for copyright reasons. For more details about these see:

http://urn.kb.se/resolve?urn=urn:nbn:se:liu:diva-127148 